\title{
Islam and Foreign Policy: Turkey's Ambivalent Religious Soft Power in the Authoritarian Turn
}

\author{
Ahmet Erdi Ozturk 1,2 \\ 1 School of Social Science, London Metropolitan University, London N7 8DB, UK; e.ozturk@londonmet.ac.uk \\ 2 Turkey Programme, The Hellenic Foundation for European and Foreign Policy (ELIAMEP), \\ 10676 Athens, Greece
}

\begin{abstract}
Although the pro-democracy agenda of Turkey's Justice and Development Party (Adalet ve Kalkınma Partisi, AKP) gained significant domestic and international credibility throughout the early 2000s, the party has, since approximately 2010, experienced a dramatic process of democratic decline. The AKP has intensively used Islamist policies at home and abroad to consolidate its base of support under the leadership of President Recep Tayyip Erdoğan. Weaponised in foreign policy, Islam has become both an instrument and an objective of the repressive AKP, and Turkey has emerged as a front runner in a race among countries increasingly using religion as a foreign policy tool. This new role for Turkey has created a slew of disparate perceptions among foreign countries. While some are content with Turkey's religiously fuelled policies and designate Turkey as an influential actor which can use Islam as a soft power tool, others refuse to define Turkey's policies within the boundaries of soft power due to its extra-territorial authoritarian practices. This study defines Turkey's Islamic soft power as ambivalent and scrutinises the reasons behind this ambiguity by exploring examples from other countries in South-eastern and Western Europe.
\end{abstract}

Keywords: Islam; foreign policy; soft power; authoritarianism; Turkey

Citation: Ozturk, Ahmet Erdi. 2021. Islam and Foreign Policy: Turkey's Ambivalent Religious Soft Power in the Authoritarian Turn. Religions 12: 38. https://doi.org/10.3390/rel 12010038

Received: 13 November 2020 Accepted: 6 January 2021 Published: 8 January 2021

Publisher's Note: MDPI stays neutral with regard to jurisdictional clai$\mathrm{ms}$ in published maps and institutional affiliations.

Copyright: () 2021 by the author. Licensee MDPI, Basel, Switzerland. This article is an open access article distributed under the terms and conditions of the Creative Commons Attribution (CC BY) license (https:// creativecommons.org/licenses/by/ $4.0 /)$.

\section{Introduction}

This article seeks to delineate how Turkey's Justice and Development Party (Adalet ve Kalkınma Partisi, AKP) utilised Islam as a foreign policy tool and whether this pertained directly to changes in domestic political balances in Turkey. Furthermore, it scrutinises the different usages of Islam by the state structure and Islamic communities as a foreign policy tool. In this regard, this study will firstly utilise the literature on religious soft power to discuss the role of Islamic religious soft power in foreign policy. Secondly, based on a series of interviews, this study will scrutinise how various segments of different nations perceive Turkey's rather distinct use of Islam in foreign policy. This article will also investigate the utilisation of Islam, first in domestic policy and later in foreign policy, and the various manifestations of this use at the behest of an authoritarian power.

Turkey constitutionally codified secularism (laiklik), which is quite different than the French laïcité, as its state identity in 1937 (Kuru 2009). Although, in the case of Turkey, the state claims, as a principal discourse, to have essentially separated Islam from state affairs, Turkey brandishes Islam as both an end and a socio-political means with mosques and religious organisations established amidst this constitutional secularism initially within its own borders and subsequently abroad. It is important to note that, since the beginning of the history of the contemporary Turkey, Islam has always been an element of domestic and foreign policy. Indeed, the role of Islam was limited within the domestic political sphere during the tenure of the founding leader, Mustafa Kemal Ataturk, and even until the late 1960s, but Turkey began using Islam as a foreign policy tool in the early 1970s (Ozturk 2018). The utilisation of Islam in this manner, both in domestic politics and foreign relations, is consistent with the acknowledged return of religion to global politics, with 
the Iranian Revolution and successive religious incidents that erupted around the world (Cesari 2014; Philpott 2009).

It is also congruous with the understanding that religion is positioned between the state identity, civilisation and elements of power (Cesari 2019; Fox 2018, p. 197; Gill and Keshavarzian 1999, p. 433). Though Turkey has, throughout its history, weaponised Islam domestically and internationally, this action has always materialised with a unique hesitation. Under the AKP, which rose to power in 2002 and has remained the sole political authority for nearly twenty years, Turkey is ruled by an administration that has prioritised Islamic values, gradually engendered authoritarianism and triggered changes in the state identity following numerous socio-political events (Baser and Ozturk 2017). The current power-holders utilise Islam as an element of influence. Although Islam allegedly finds use in Turkey as a key agent of power, especially in foreign policy, how and with which limitations one can define this element of power are topics that have not often been the subjects of debate and are constrained by descriptive explanations.

Turkey began establishing mosques and training imams in Western Europe in 1970s and in both Asia and the Balkans starting in the 1990s, upon the explicit invitation of foreign states (Citak 2018). This initiative emerged when Muslim-majority countries realised that they were unable to deliver most Islamic religious services. Faced with the possibility that Salafi or Wahhabi groups would swoop in to fill such a gap, these states opted to accept Turkish influence, with its 'Muslim society' and secular state identity. The Presidency of Religious Affairs (Diyanet İşleri Başkanlı̆̆ı, hereinafter Diyanet)—Turkey's transnational religious state apparatus-and other non-radical Islamic associations began to foster influence beyond Turkey's borders. During the AKP era, Turkey began constructing mosques and facilitating religious services in some countries with which it possesses no historical or cultural connections, such as Cuba, Somalia and the United States, competing with Muslim-majority countries such as Saudi Arabia, Morocco and Iran to gain influence over the global Muslim population.

Although possible to scrutinise this situation through the lens of religious soft power based on Haynes' $(2007,2016)$ definition, one may argue that a collective reading of Turkish actions departs from the scope of religious soft power and attests, in this context, to the necessity of an ambiguous definition that encompasses both soft and hard power. The negative reactions from the countries that Turkey visited through Islamic and economic power, various sanctions of self-depiction and the politicisation of Islam have all contributed to this contention. The AKP, which demonstrated at the onset of its ascension to power its ability to collectively govern Islam and democracy (Insel 2003), tumbled into authoritarianism (Irak and Ozturk 2018), employing Islam as a new means of discourse, especially after 2013 (Yavuz 2019). This spawned revisions in both the state identity and perception of civilisation in Turkey (Sarfati 2017). The satisfaction many African nations felt with the new definition and discourse of civilisation does not translate to Western European countries such as Austria, France and Germany, which accuse Turkey of disseminating its own political Islam through other apparatuses, primarily the Diyanet (Ozturk and Sozeri 2018). In these countries, shuttering mosques and deporting imams under Turkey's control have recently surfaced as frequent topics of discussion. Comparable examples could be observed in the Balkans (Ozturk 2021). Furthermore, Turkey has sought to expand its religious influence from Cuba to Israel. Despite some Turkish provocation in these countries over the politicisation of Islam and Islamic institutions, financial and political support enable local religious organisations to maintain their presence and influence. But how should we define Turkey's use of Islam as a feature of power that has received negative reactions despite its moderate status in some places and extremist orientation elsewhere? On what factors do the historic changes rely in Turkey's use of Islam as an element of power? And, finally, what various responses have these changes elicited around the world?

To answer these questions, this article uses a comparative history method to focus on the changes that arose in Turkey's domestic and foreign policies between 2002 and 2020, the adjustments initiated in its state identity, the extent of democratic development, and the 
evolving operations of transnational Islamic state apparatuses and internationally active Islamic communities (Mahoney and Rueschemeyer 2003). This orientation will utilise the written materials that institutions and discourses-primarily those of the decision-making political and bureaucratic elite in Turkey-have produced regarding Turkey's injection of Islam into foreign policy. Additionally, this article will further utilise eighty-three (83) semi-structured expert interviews conducted between 2016 and 2019 in Turkey and subsequently in countries in which Turkey sustains its influence through religion, including Sweden, Germany, France, Bulgaria, Albania and North Macedonia, in order to decipher how Turkey's weaponisation of Islam in foreign policy encapsulates a hybrid power. The subjects of these interviews include representatives of Turkish policy makers, host-country diplomats, foreign policy makers and other Turkish transnational Islamic groups, such as the Gülen Movement and the Sulaimani Community (Süleymancı Cemaati).

The next section contains a theoretical discussion of religious soft power to demonstrate its hybrid nature, particularly in the case of Turkey. This study will then briefly explain the role of Islam in Turkey's foreign policy and the use of Islamic soft power starting in the late 1970s. Finally, it will explore and categorise Turkey's Islamic influence according to Turkey's critical junctions and transformative periods and based on the perceptions of the political and religious elites of host countries.

\section{Theoretical Discussions around Religious Soft Power and Beyond}

Religion is one of the oldest patterns of identity, along with gender, race, ethnicity and class (Ben-Porat 2013, p. 8). Religion also operates as a force of both divisive and unifying legitimisation in domestic and foreign policy (Fox and Sandler 2004, p. 169). Despite its status as an ancient element of power, religion was a factor omitted by classical realism due to the theories of secularisation that occupied a hegemonic position in foreign policy. Foreign policy scholars classically viewed the state as the main constituent of foreign policy, prioritising economic and military strength as elements of hard power (Baldwin 2012, p. 273). They excluded elements that exhibited more normative dispositions yet were as influential as hard power-civilisation, culture and institutional development. Nye began, in the late 1980s, to study elements such as civilisation and culture in his work on patterns of soft power, which he defined as the competence of a state to coerce another state to exact its bidding without using power or force (Nye 2004, p. 101). He argues that countries can achieve their objectives without coercion, but the notion that religion could be soft power first penetrated the scholarly debate only at the turn of the century (Thomas 2005; Haynes 2007, 2016; Steiner 2011). Religion may fundamentally be an element of soft power, and it may find use both positively and negatively in canalising various ideologies and modifying patterns of behaviour. Pope Francis' contribution to the Paris Climate Accords (Jacquet and Jamieson 2016) or the events that the Organisation of Islamic Cooperation hosted for higher education and global peace could no doubt be interpreted as variants of soft power-or as examples of the use of religion and its teachings as instruments of soft power (Lee 2015). However, considering the ambivalent instrumentalisation of religion, one could argue that some terrorist groups utilise religion for discursive persuasion, thus propelling the relationship between religion and soft power to a wholly different dimension.

In the underlying challenge of states to use soft power, it becomes apparent that it is impossible to use Islam solely as a soft power. For instance, most Middle Eastern and North African countries, but especially Iran, Saudi Arabia, Qatar, Morocco and Turkey, have for some time been invested in a state of global competition for the dominance of their own Islamic values, and they have used Islam as an instrument of foreign policy (Cesari 2009; Wastnidge 2015; Al-Rasheed 2008). This, on the one hand, embodies a conflict between various religious interpretations and, on the other hand, concerns the economic powers of nations, their global perceptions and the structures of institutions they manipulate in domestic and foreign policy. Bettiza (2020) argues that some states may possess consequential religious resources, among which is the use of religion in foreign 
policy through symbolic, cultural and network-based elements, that may transcend the general concept of soft power.

In their recent study, Mandaville and Hamid (2018) emphasise the numerous ways in which reliance on the transnational use of religion appears despite the inconsistent use of the concept of soft power. They identified three aspects that states possess regarding transnational religious soft power: their institutional and normative capacity and civilisational affinity, their socio-political circumstances and the aims of those seeking to wield religious soft power, and the double-edged sword structure of religious soft power. While states display their religious influence and power in the international arena, external appearances do not pertain merely to their religious identities or instrumentalisation of religion (Rudolph 2018, p. 16). Fundamentally, and consistent with this power, its perception as an element of religious power in the eyes of states concerns the intrinsic elements of both soft and hard powers. This differentiates them from other social structures and from institutions that are non-state elements of power.

A consideration of the variance of problematic regimes, weak democracies and assorted definitions of civilisation (e.g., Saudi Arabia and Iran) from the geography in which they strive to be influential lends itself to the assertion that the elements of civilisation are conspicuous in how they are perceived. Although Turkey has adopted a Western form of modernisation, its evolving perception of civilisation, especially in the 2000s (Capan and Zarakol 2019), may have altered the policies of influence and power it implemented over religion. Secondly, the view of transnational Islamic services as essentially and eminently beneficial for diaspora groups (Bruce 2018) highlights the diaspora policies of nations as a point that influences the relationship between established services and power. Considering the possibility that the state identities of some leader-based countries undergo leader-based change and reflecting on the pertinence of many characteristic foreign policy practices to the state identity, civilisation in particular (Rumelili and Todd 2018) unveils the extent to which nations' use of religion as a force in foreign policy alters the policy making strategies of leaders and the foreign policy practices of states.

States' adoption of religion in foreign policy or their efforts to amass influence by playing the religion card implies the existence of soft power, because religion does not originate from the classical elements of hard power. However, it fundamentally merits a definition both inside and outside of soft power. The historical, cultural, diplomatic and economic relationships that states establish with other states in this context warrant consideration alongside various elements that function as indicators within the interaction and perception of religious apparatuses. This concept is central to the perspective as an element of soft and hard power and, moreover, advances it to the status of a component of the relationship. The explication of how nations implement religion-based foreign policy, considering religion an instrument and understanding the extent to which religion embodies a hybrid power, necessitates a multifaceted study extending from domestic to international politics.

\section{Turkey as a Nascent Islamic Soft Power}

If I must speak specifically for Germany, Turkey and its religious institutions have become salient and reliable organisations for us in the last quarter of this past century. Ethnic and religious services, initially to Turks and subsequently to the other Muslims within our borders, were important issues, and we are happy to have been able to sit down and discuss our shared values and to have done this with a country that possesses an understanding consistent with our society. We no doubt experienced minute problems every once in a while, but these were insignificant issues. Ultimately, Turkey served with us for approximately the past quarter century in this society by understanding us and without straying from its own values. I think other European countries also believe the same regarding the past quarter century.

During an interview on 7 June 2019, a senior bureaucrat from the German Federal Foreign Office (Auswärtiges Amt) in Berlin stressed that Turkey's Islamic institutions have 
operated consistently with German and Western values at least throughout the past century. Managing these institutions no doubt pertains to the norms, histories, perceptions of civilisation and national identities of countries, whether religious or secular, in order to determine the extent to which these institutions possess power in domestic and foreign politics. Institutional influence in foreign politics certainly concerns the identities of their representative states. As Wendt (1994) noted, identities fundamentally emerge from the multidimensional interaction of institutions within the historical process of society and the state, and these identities reveal the origin and progression through which states cultivate how the international arena perceives them.

Islam occupies a central position in discussions of state identity, society and their perception around the world specific to Turkey. In the Ottoman Empire, Islam determined an assortment of other statuses in addition to citizenship from the state (Yavuz 2003, p. 38) and continued to maintain its determinant position in modern Turkey. But its implication for the state began to change. Turkey's founding elite accepted the state's control of religion, which crystallised in the first quarter of the nineteenth century but whose earlier roots date back to the Byzantine Empire, as well as the legacy domination of a singular type of religious understanding in society. Although the founding elite defined the new state identity through a lens of laicism, a unique mechanism of control emerged with its practices (Davison 2003). The Kemalist founding cadre claimed to have enacted radical changes like nearly all founding and revolutionary movements yet resorted to designating and imposing on society its own interpretation of Islam. They defined Ottoman-era Islamic religious practices and Islamic congregations in a pejorative manner, imputing it with outdated customs, and presented norms as modern and wholesome (Toprak 1981, p. 33). They projected a Comtean positivism with the legal and institutional domain of control over religion, far removed from a Lockean understanding that hinged on the principle of church-state separation (Kadioglu 1998, p. 8). In this notion of control synthesised with nationalism, the status of 'desirable citizen' was to remain within the Sunni Islam mould the state carved out. The state shuttered Islamic communal organisations and all institutions remaining from the Ottoman Empire and, in 1924, founded the Diyanet under its own control. This was the same year that the founders of the Republic of Turkey abolished the Caliphate. Although its official public emergence did not occur until later, the Diyanet began to regulate and subdue the domain of religion for, and on behalf of, the state.

The state's control and regulation of Islam inherently relied on two traits of the republic's founding cadre: their perceptions of modernisation and their positioning of religion. Turkey's founding elite, harbouring an understanding of civilisation synthesised primarily with nationalism and positivism (Bora 2003, p. 436), sought to Turkify Islam in a manner that prioritised Turkishness and correlated religion with an institution loyal to the Turkish state. Beneath the ceding of religion to the control of an institutional structure lay both the eschewing of religion and the desire to implement religious power in order to establish the state (Kuru 2007, p. 588). By outlawing Islamic communal organisations, they absorbed Islam into the state monopoly and attempted to eliminate a power that might have bolstered opposition to their own political dominance. And they used Islam as an unspoken, foundational element of the state, aware of its potency as a societal and political force. Islam always pervades at the nucleus of the state and society and where the state merges with society. As Cesari (2019) notes, due to early republican policies, Islam has become the focal point of the national identity in Turkey and has started to affect Turkey's policy preferences.

In Turkey, which implemented a multiparty political system in 1946, Islam has always been standing at the core of politics for both political parties such as Republican People's Party (Cumhuriyet Halk Partisi, CHP), the Democrat Party (Democrat Parti, DP). Furthermore, religious communities have been the other active actors of politics (Keyman 2007, p. 223). The Naqshbandi and other religious communal organisations were relatively silent before 1950 but later gradually proliferated, ascending in the domain of 
religion (Ozdalga 2010, p. 72). Nearly all varieties of political configuration that noticed the impact of Islam on current politics and the shares of votes began to foster relationships with these Islamic organisations. But it is unclear whether these relationships of rapprochement and mutual control established with Islam instilled change in Turkey's raison d'état and understanding of civilisation. Although political parties-not the least of which being that of the Islamist politician Necmettin Erbakan-that flaunted their affinity to Islam came to power in Turkey, especially between 1950 and 2002, they failed to modify Turkey's raison d'état or perception of civilisation.

Nevertheless, the military interventions in 1960, 1971 and 1980 legally advanced the societal power, reach and influence of the Diyanet and made the institution a more powerful ideological apparatus of the state (Ozturk 2016). Diyanet was coded to preserve both nationalism and societal integrity in domestic politics in the early 1960s and was forced to facilitate covert collaboration with religious communal organisations, domestically and internationally.

In the 1970s, we started working with members of different religious organisations, both within the country and abroad. The quintessential reason for this was, unfortunately, that the state remained relatively inadequate economically and as a human resource. But our main criterion here was that these religious organisations complied with our general principles. These were the existence and integrity of the Republic of Turkey.

In an interview I conducted in January 2016 at the head office of the Diyanet in Ankara, a senior executive expressed, as the excerpt above illustrates, that the institution started collaborating domestically and internationally with outlawed Islamic organisations starting in the 1970s. Though not a novel concept in domestic politics, Turkey's provision of Islamic services in foreign nations with its secular strength is not widely known. The Turkish Diyanet Foundation (Turan 2008), whose operations commenced in 1975, and other institutions that were loyal to Turkey and sought to fulfil these religious services aided Turkey in establishing the Turkish-Islamic Union for Religious Affairs (Diyanet İşleri Türk-İslam Birliği, DITIB) in Germany in the mid-1980s. Turkey began to provide religious services, first to its own diaspora and later to other Muslims, amassing influence in this context. But these services do not constitute the direct use of religion as a soft power, because they were routinised services. However, it is important to note that these services relate to a limited region, as different circumstances prevail in the Balkans, Africa and elsewhere.

Turkey essentially was always interested in us but only managed to provide religious services here in the 1990s for several reasons. But I think these services were not very influential until the 2000s because of economic shortcomings. This service was pivotal through some religious organisations coming from Turkey.

Speaking to us in an April 2017 interview, Bulgarian Head Mufti Hac1 Alis described the situation not only in Bulgaria but also in other Balkan nations with large Muslim populations. However, as former Albanian Minister of State Genc Polo noted in May 2017, Bulgaria, Albania and North Macedonia personally invited Turkey to provide services through the Diyanet, primarily due to its secular state structure and its cultural and historical affinity to the region. Turkey also began to provide services in other Balkan nations through assistance and other indirect means. But the initial instability of its domestic politics and, subsequently, economic issues in this process prevented Turkey from completely fulfilling its services. Nevertheless, the Gülen Movement filled this gap at Özal's personal initiative in the 1980s and later with the support of other political actors. But the presence of the Gülen Movement, particularly in the Balkans, is more convoluted than it seems.

We, as a movement, were a structure that Turkey did not want in the 1980s and 1990s. We began opening schools first in Albania and later in other Balkan nations with the letters of reference from the late Özal, but we provided no religious services. This is not in our nature. We did, however, support muftis in struggling nations through our business colleagues. 
Although the Gülen Movement did not directly provide Islamic education, its members did indirectly support and establish relations with Islamic institutions. The above statement, from a North Macedonian Gülen Movement official in February 2018, indicates that the Movement did not fully represent an alternative or auxiliary structure to Turkey's regional presence in foreign politics prior to the 2000s. Nevertheless, the Gülen Movement undisputedly compelled the region to accept itself as a Turkish actor on issues of education and finance. This situation predominantly indicates that another non-state religious actor from Turkey sought to avoid religious conflict with the values of other nations while prevailing as an element of power and influence, especially in the Balkans. Thus, the extent to which the Diyanet carved out a space for itself in Western Europe translated to the Gülen Movement's similar adoption of space in the Balkans in the final decade of the twentieth century. But it is impossible to describe this situation, in which economics also played a role, as soft power.

Other Turkish-originated Islamic structures failed to duplicate the success the Gülen Movement found using the powers of Islam, education and finance. Despite the influence that the Sulaymanites, Naqshbandis and the Erbakan-affiliated Millî Görüş movement brandished in countries with high populations of Turkish migrants-primarily Germany, France, Belgium, the Netherlands and Sweden (Ostergaard-Nielsen 2003) —almost no host states perceived these religious organisations as colluding with Turkey or as its alternative power. This was due to their divergent views on civilisation and the international space relative to secular Turkey as well as their inability to assent on a level shared with Western nations. However, the Gülen Movement sought to nurture interaction with the political and economic elites of nations as much as with Turkish migrants and other Muslim groups. This situation warrants the label of the Islamic influence and, somewhat, religious soft power that the Diyanet created in Europe with the Gülen Movement and other Islamic organisations under the control of Turkey's secular state configuration. This power and influence underwent profound change during the AKP era.

Three elements structurally relate to this historical background:

(A) Foreign countries have long perceived Turkey positively and harmoniously as a nation whose civilisational aims embodied a 'Western' nature. This is despite its maintaining and unceasingly increasing its influence as a component of religious policy and culture since its founding.

(B) Turkey also viewed its target of modern civilisation in domestic politics as Western and sought to co-exist in other nations with Muslim groups that distanced themselves from laicism and radical philosophy as a state identity. And it failed to fully realise religion as an instrument of soft power due to insufficient institutional capacity, primarily in the Diyanet (Gurses and Ozturk 2020, p. 330). Turkey aimed to serve primarily its own diaspora and cognate groups despite its positive reputation in the eyes of the elites of other nations, yet it failed to cultivate the power of sanction in other societies over its own compliant understanding of Islam and its laicist state identity.

(C) Nevertheless, the relations Turkey formed represent a significant infrastructure, although it did not operate with full capacity, and Turkey employed this infrastructure to effect change in the 2000s.

\section{Turkey's Authoritarian Drift under the AKP Rule and Its Impact to the Foreign Policy}

From 1960 until the AKP rose to power in 2002, thirty-three separate governments ruled Turkey in increments of less than two years. Apart from the Motherland Party (Anavatan Partisi, ANAP) government between 1983 and 1991, no party managed to singlehandedly rule the country. The governance problems-primarily poor economic policythat plagued Turkey during these years, which were devoid of stability in domestic politics (Onis 2010), were generally blamed for issues such as Turkey's inability to attain full EU membership (Muftuler-Bac 1998). The AKP, backing the notion that it could solve the 
problems of single-party rule, rose to power in 2002 having received votes from massively diverse segments of society in a catch-all party strategy. The party showcased figures who prevailed in different positions of Turkey's conservative, liberal and ideological ecosystem. Although Turkey's secular elite and institutions eyed the regime's progression with suspicion, this development bolstered claims of 'Muslim Democracy'. This proceeded to elicit the hope that foreign values of democracy and domestic Islamic values could coexist and, moreover, that a majority of administrators whose religious values prominently featured the laicist state identity could exist in Muslim societies.

Contrary to this positive emergence, the AKP government, over the past 20 years, has become the political regime that has reflected arguably the greatest changes in the shortest amount of time in Turkish domestic and foreign policy. Turkey began to be defined as a hybrid regime, with its quality of democracy plummeting in recent years (Esen and Gumuscu 2016). The deteriorating relationship Turkey cultivated with democracy neither occurs without consequence nor is a phenomenon with one-dimensional repercussions. This is the state of a multifaceted transformation-which affects many circumstances such as state identity, perception of civilisation and processes of constructing domestic and foreign policy-that can be unravelled only numerically. The aggregate of this change is in some ways bound to incidents Turkey experienced in its domestic policies and also to influences its international perception. Islam is known to fill a salient role within this transformation (Yavuz and Ozturk 2019), but it was not only internally that this was noticed. In September 2018, a senior official from the French Ministry of Foreign Affairs offered this summation:

The change Turkey has undergone in recent years is, from our perspective, inherently shocking. Under the leadership of Erdoğan, it has transformed from a country partial to democracy and the European Union into an aggressive nation that synthesises Islam and nationalism. This certainly did not directly affect our relations, yet it has indirectly influenced our relationships with Turkey and its institutions.

French officials' views on Turkey resemble the intersection of arguments that Turkey rapidly transformed under Erdoğan's leadership by synthesising Islam with nationalism as an instrument (Kaya 2015). Nevertheless, a Muslim politician in the North Macedonian city of Tetova voiced different opinions in April 2017 regarding Turkey's relationships with Islam and the state, the reverberation of this in foreign policy and Turkey's utilisation of religion and religious institutions in foreign policy:

I know, all Westerners are saying about Turkey is that this country underwent a negative transformation, that it became Islamised, slid into authoritarianism and is no longer as it used to be. I do not agree with these views, and believe me, many Muslims in [North] Macedonia and the Balkans also do not agree. I think some bad incidents have turned Turkey into itself. The Gezi uprising, the coup attempt and the games of the Gülenist terrorists have brought Turkey inward, creating a shock effect. Anymore, there is a Turkey that protects its siblings, its cognates and was not meek. The West does not like this.

The French bureaucrat and the North Macedonian political figure make basically the same claim but from different perspectives. These variations no doubt pertain to the cultural, political, historical and religious codes they bear from their respective geographies. However, they mentioned a partnership other than the discourse through which Turkey engages in a consequential transformation: Turkey's various Islamic influences and its elements that utilise Islam. One can contextually interpret Turkey's perception of civilisation and utilisation of Islam as instruments of foreign policy, starting with its institutional capacity, using a structuralist approach based on changes in domestic politics (Aydin-Duzgit 2018).

Under these circumstances, one can interpret in four stages the AKP's trajectory in domestic politics and the conditions that this nourished with the influence of religion in foreign policy (Table 1). Moreover, as was stated above, one can assert that the intersection of these changes marshalled the underlying reasons for Turkey's inability to fully wield 
Islam as a soft power and also its subsequent crafting of this power into an instrument with hybrid influence.

Table 1. Turkey's AKP's Political Journey and its Attitudes in Domestic and Foreign Policy.

\begin{tabular}{|c|c|c|}
\hline Period & Critical Junctions & Party Attitudes in Domestic Politics and in Foreign Policy \\
\hline 2002-2008 Survival & $\begin{array}{l}\text { E-memorandum } \\
\text { Republican Meetings }\end{array}$ & Defensive/Recessive \\
\hline 2008-2013 Takeover & $\begin{array}{l}\text { Ergenekon and Sledgehammer (Balyoz) } \\
\text { Trials } \\
\text { KCK Operations }\end{array}$ & Active/Strategic \\
\hline 2013-2016 Challenge & $\begin{array}{l}\text { Gezi Park Protests } \\
\text { 17-25 December Corruption } \\
\text { Investigations }\end{array}$ & Reactive/Aggressive \\
\hline 2016- Hegemonic & 15 July Failed Coup Attempt & Aggressive/Aggressive \\
\hline
\end{tabular}

\section{Turkey: An Ambivalent Religious Soft Power}

Swedish relations with Turkey no doubt accelerated further in the 1960s with the commencing labour migration. They later transitioned to a new dimension with the arrival of Turkish Kurds and Alevis, but the formation of associations in the mid-1980s and the subsequent support from Turkish governments for these organisations-or desire that they not form - gravely impacted the perception of Turkey.

The mention of associations Turkey supported by a senior-level official from the Swedish Institute in May 2018 was, no doubt, the Swedish branch of the Turkish Diyanet Foundation, which was formed in 1984 in nations hosting large populations of Turkish migrants such as Germany, France and The Netherlands. Although this foundation today provides services in eight mosques across Sweden with more than ten imams, it occupied this dimension of influence neither in the 1980s or 1990s nor in the 2000s when the AKP government came to power. Despite the resonating claims that international religious institutions and their activities began to fuel perceptions as means of Turkish soft power, especially when the AKP government assumed control (Oguzlu 2007), the reality around the world somewhat deviates from this assertion. The greatest reason for this divergence is that Turkey was unable to fully escape from either the changes it experienced in its domestic politics or the role of religion in these changes. A relative shift occurred in Turkey's instrumental use of Islam and Islamic institutions during the early years of the AKP government, but definitions of soft power appear unable to illustrate this.

After 2002, Turkey's interest in our country and our institution no doubt began to gradually increase. However, I could not say that this interest pertained directly to religion. It was significant that religious individuals were in power in Turkey, but they were unable to employ religion significantly. In this period, they refrained from further making religion felt, because their religiosity caused them trouble in domestic politics. However, monetary aid grew relatively during this period, and, to be honest, we ended up sensing Turkey more in our institution.

The points that former Head Mufti of the Muslim Community of Albania Skëndër Bruçaj described in our April 2017 interview regarding financial assistance and problems originating from domestic politics were common themes among the individuals we interviewed in other Balkan nations and in Germany, Sweden and France. For example, Turkey began to construct more mosques in Western European countries while providing monetary assistance in comparatively larger amounts and more regular intervals to the offices of muftis in other Balkan nations, particularly Bulgaria and North Macedonia. Another example appears with the Diyanet's delivery of monthly cash assistance to the Office of the Bulgarian Mufti starting in 2004 while concurrently providing cash assistance to, and meeting various other needs of, the offices of muftis in other Balkan nations (Ozturk and Sozeri 2018). The relative economic improvement Turkey exhibited 
with the rise of the AKP government spawned an increase in the Diyanet's institutional capacity and international reach. But neither a mere increase in such capacity nor the instrumentalisation of the economy for the benefit of religious institutions fit the definition of soft power. Moreover, as noted above, turmoil in domestic Turkish politics obstructed the effective utilisation of religion in foreign politics.

One can assert that the AKP engaged in a struggle for survival, particularly between 2008 and 2009, against secular and Kemalist tutelage forces in domestic politics. The Islamist history of AKP administrative cadres, the relationships they established with Islamic communities, the headscarves their wives donned and the heightened inclusion of AKP members in the public sphere spawned the notion that the army claiming to be Turkey's true guardian allowed the power to rule to be snatched from its grasp in the Kemalist judiciary and bureaucracy (Ozturk and Gozaydin 2017, p. 218). The AKP principle of supporting rights in this political domain prompted a societal rivalry of influence between the other foci of power, extending to the highest levels of the state. This struggle, which the secular configuration mounted against structures that prioritised religious values, appeared in the form of Republican Rallies, in which the public took to the streets and filed lawsuits to force the end of the AKP (Turan 2008). However, the AKP emerged victorious from these struggles thanks to its electoral support and other auxiliary elements. Among these was the Gülen Movement, which established an 'unconventional-informal coalition' with the AKP both domestically and internationally. As was previously mentioned, the Gülen Movement stepped into the public sphere in the late 1990s as an understanding of Islam that was scientific and Western conforming. The Gülen Movement engaged in positive lobbying efforts for the AKP during this era in nations where it maintained a presence (Watmough and Ozturk 2018). Prominent members of the Gülen Movement with whom I spoke in 2017 and 2018 in Sweden and Germany stated that the AKP defended them in Europe, especially during its early era, as a group that could manifest democracy and Islam together. Moreover, they stated that these foreign forces occupy a dimension separate from Turkey's Islamic soft power. The assertion here is that the Gülen Movement is a multidimensional configuration that emerged from the secular Turkish state, synthesises education with a moderate understanding of religion and can influence elites in the countries where its presence endures. Those who define the Movement in this manner claim that it is organically Turkey's parallel religious soft power. In this context, the Gülen Movement could conceivably be a soft power that effectively prioritised religion abroad during the years when Turkey practiced 'Defensive-Recessive' domestic and foreign policies. But one cannot merely designate the Gülen Movement a soft power.

Gülenists have existed since the 1990s—-that is true. It is also true that they are part of a Muslim movement, but they concern themselves more with education, trade and, indirectly, with politics. They contributed to us in the early 2000s, but we received no religious support from them, because that was not their direct priority. Our relations prevailed more on issues of education and finance.

What an interview subject, who served as an influential official in the Islamic Religious Community of North Macedonia between 2006 and 2008, conveyed to me in April 2017 is similarly valid for many Balkan nations. For example, the Bulgarian Mufti said that the office of the mufti received significant financial support from the Gülen Movement on these same dates. However, almost none of the decision-makers in Balkan states from that time stated that the Gülen Movement contributed directly or positively to perceptions of Turkey or the AKP. Likewise, the Movement conceivably had nominal influence, entering into the scope of effective Islamic soft power, considering that it engaged more with its own members and other diaspora groups in Western Europe.

The era in which Turkey sought to survive in domestic and foreign policy under the AKP government ended in 2009, when it shifted to the counter-offensive in domestic politics. From then until at least 2013, the AKP managed to, in some manner, immobilise the Kemalist and secular elite thanks to the unconventional-informal coalition it had established 
with the Gülen Movement. And it began to legally reduce the influence of transnational state apparatuses domestically with the help of propaganda through the Ergenekon and Balyoz cases as well as internationally. AKP governments plausibly pursued a more active and strategic policy. It was at this time that a new actor emerged: Ahmet Davutoğlu, who served as foreign minister between 2009 and 2014 and as prime minister between 2014 and 2016. He strove to comprehensively modify Turkey's classic understanding of foreign politics Turkey, including during early AKP rule, along an axis of Islam, culture and civilisation.

According to Davutoğlu, Turkey occupied its own unique realm of civilisation and, thus, must abandon its attempts at beautifying the form of Western civilisation upon which it had relied since the early Republican Era. Turkey, he believed, could rise to a leading position first in the region and then throughout the Muslim World with a synthesis of Islamic values and the culture and perception of civilisation incepted with the first Turkish states. Turkey could compete with Western civilisation with this leadership (Ozkan 2014). Fusing history, Islam, nationalism and perceptions of civilisation, oneparty governance within this philosophy and its spontaneous occupation of the dominant viewpoint, Davutoğlu's understanding delivered three outcomes:

(1) The ideology of foreign policy that prioritised secularism, harmony with the West and issues of security began to change.

(2) Turkey ultimately further applied Islam in foreign policy on a discursive and instrumental level and began to gain active foreign policy practice with this revision. All of Turkey's other transnational state apparatuses, and primarily the Diyanet, started to appear more visibly in the countries where they maintained a presence, utilising religion with this newfound mobility.

(3) This actively nationalist and Islamic understanding of foreign politics culminated in the transition from Western-oriented language in Erdoğan's leadership discourse to a focus on the ummah - the Muslim community - and Islam.

This is one of the most critical indicators of Turkey's entrance into the race with other Muslim nations for the leadership of the global ummah. Both the expanded areas of operations for transnational state apparatuses and the broadened use of religion in foreign politics could warrant interpretation as an increase in Turkey's soft power based on descriptions by Mandaville and Hamid. Moreover, numerous researchers have studied this period as an increase in the orientation of soft power in Turkey's foreign policy (Ipek 2015). However, policy makers in different regions did not fully interpret this sudden change in the perception of civilisation in this manner. For example, a senior official in the German Ministry of Foreign Affairs whom I interviewed in 2019 communicated that Turkey might lay bare security issues by distancing itself from Western values and further contributing to the widening polarisation of religion in Europe, becoming engrossed in a foreign policy predicated on Islamic discourse. In addition to this anxiety along the axis of security, the French and Swedish policy makers whom I interviewed suggested that Turkish foreign policy entered an axial dislocation that weighed heavily on the aspect of religion.

Turkish diplomats and policy makers, however, definitively reject all these assertions of religious axial shifts. For example, former Turkish Ambassador to Sofia Süleyman Gökçe, whom I interviewed in May 2017, claimed that no such axial dislocation existed in Turkish foreign policy and, conversely, that Turkey had adopted a more active foreign policy that everyone had embraced. But statements on the same dates from a senior foreign affairs official working in the Bulgarian Office of the Mufti encapsulate the situation more clearly:

Whoever says that Turkey's understanding of foreign policy did not begin to change after 2010 is unperceptive or lying. Turkey's foreign policy shifted to a more nationalist and religious dimension. It is more active in the Diyanet and other instruments. I actually am pleased with this. Anymore, there is a foreign policy that understands us Muslims. But at the same time, this is a highly active policy that is very much making its voice heard. This is particularly good for us, yes, but also incredibly harmful, because this disturbs the 
non-Muslim elite and public with whom we co-exist. When they become uncomfortable, we all may become uneasy. It is important for Turkey to retain its balance here.

Turkey's relative side-lining of the Gülen Movement and Kemalist and secular forces in its domestic policy revealed itself in a novel manner, especially after 2008, by merging Davutoğlu's foreign policy influence with Erdoğan's claims of leadership. This situation highlights Islam and nationalism by deviating from the customary understanding of civilisation and, at first glance, embodies an interpretation of active foreign policy and religious soft power. But in essence, it harbours a hybrid concept. This foreign policy, on the one hand, pleases Muslims and, on the other hand, frightens Muslims and other groups in various manners, primarily in relation to security. Turkey's use of religion to depict itself as a state through the focus of civilisation prompted distinct reactions in separate groups.

\section{Turkey's Hybrid Religious Soft Power Implementations}

From 2002 to the early 2010s, Turkey underwent a binary transformation through the use of Islam in foreign policy, relating to developments in domestic politics. AKP administrators, who heavily emphasised Islamic values between 2002 and 2007, de-prioritised religious precedents, as if to prove that Muslim political actors could implement secular domestic and foreign policies. However, once they felt unrivalled in domestic politics, they began to modify the instruments, strategies and language they used with the perception of civilisation centred around religion and nationalism. Fundamentally, although this change could functionalise Islamic institutions and did not create anxiety by synthesising secularism with Islam, Turkey would surely embody a nation that effectively employs Islamic soft power. During the same period, foreign nations sought to perceive the change in Turkey, while a Turkish structure that emerged with schools, civil society activity and educational institutions was the Gülen Movement. For instance, in addition to Erdoğan and Davutoğlu, Gülen had also ranked on the list of the most influential Muslims in the world published since 2004. Nevertheless, each member of the political elite I spoke with in the Balkans and Western Europe between 2016 and 2019 emphasised that Gülen Movement operations would not directly deviate from those of Turkey. A senior Turkish diplomat provided a consequential explanation in April 2016:

We were forced to support the operations of this organisation at the behest of either the Ministry of Foreign Affairs or the prime minister, until at least the first quarter of 2013. We may not have provided any direct financial assistance, but we used our own political credit for them, arranged connections and supported their operations. Even if we had not done any of that, we attended their events and earned them legitimacy. And, although not a state policy, we did this in the context of government policy.

From this viewpoint, one cannot observe the policies that formed after Turkey's orientation towards Islam within the perception of civilisation it recently defined in foreign policy through synthesis with nationalism. However, the emergent effects of cooperation from interest-based relationships in calculations of internal politics between the Gülen Movement and AKP become increasingly difficult to discern within definitions of soft power. But one must note that primarily Muslim groups and later state elites acknowledged them to some extent in nations where they were influential. In this sense, the status of Islamic soft power confronting us in a hybrid manner, especially after 2013, yielded to a unique phenomenon with the turbulence that erupted in Turkish domestic politics.

Erdoğan and his party, rising to prominence with their emphasis on laicism during the Arab Spring, began to suddenly and swiftly enact a harsh crackdown, shifting to authoritarianism after the Gezi Protests that persisted throughout the summer of 2013, although the Arab Spring had little effect for Turkey (Tugal 2013). From within this burgeoning authoritarianism emerged the processes of focusing on religion in the political discourse and, subsequently, producing a unique means of legitimisation. The domestic and foreign policies of an increasingly aggressive Turkey began their authoritarian transition with the Arab Spring and the Gezi protests. The conflict-based clash of the AKP and Gülen Movement, which had long tread covertly but suddenly burst into the open after 2013, 
profoundly impacted domestic and foreign policies. The AKP maintained, on the one hand, its descent into authoritarian and, on the other hand, religious adjustments to the perception of civilisation that materialised in the Davutoğlu era. With the 2016 coup attempt and subsequent systemic changes, the Erdoğan regime pushed similar modifications to the state identity and continued to insist on situating the new governance on a foundation of nationalist and religious discourse. As it pursued political dominance by consolidating its own structure of internal political support, it ensured its domestic legitimacy with a reactive approach and an international base of religious backing. But these circumstances accompanied new elements that hinged on religion.

The influence of the Diyanet in domestic and foreign policy undoubtedly increased in a manner incomparable to previous periods. The visibility of the institution grew in domestic policy due to the binary, official collaboration it constructed with various ministries-especially the Ministry of National Education-and the Diyanet notably assumed a prominent position in state protocols. Having ranked fifty-first on the former list, the Diyanet ranked tenth after 2012. The constitution that emerged due to the amendments ratified on 16 April 2017 also bound the Diyanet directly to the office of the president. This is another indicator of the extent to which Turkey's evolving state identity actually changed. The institution, whose budget and number of personnel grow each year, flaunts its influence outside of Turkey. A senior French Foreign Ministry official with whom I met in Paris in October 2018 stated that Turkey's representatives were, of course, ambassadors and foreign officers. But the official articulated that the Diyanet is so effective that, with so much economic assistance, it no longer seeks to access Turkish migrants and French Muslims, explicitly saying, 'We are forced to see them as actors too.'

The increase in the Diyanet's area of influence and the transnational nature of the struggle between the Gülen Movement and the AKP prompted new measures in the utilisation of religion and religious institutions in foreign countries. As Glasius (2018) noted, Turkey exhibited extra-territorial authoritarian practices and began to instrumentalise the Diyanet as such. According to a report the German government published in 2017, Turkish imams in the more than thirty countries where they provide services accused members of the Gülen Movement of engaging in intelligence operations by spying on Turkey. Many foreign state officials with whom we met also claimed that Turkey resorted to uncommon measures in order to break the influence of the Gülen Movement. A senior official from the Albanian Ministry for Europe and Foreign Affairs offered the most clarifying statement in an interview in April 2017:

We are discussing two structures that know each other well. They worked together for years and, for this reason, know each other's weaknesses. Here, on the one hand, the AKP is terrorising the Gülen Movement, and on the other hand, the Gülen Movement accuses the AKP of exploiting religion, crimes of corruption and falling into authoritarianism. The two movements accuse one another of being sacrilegious and supporting structures that might be adversarial to the other. This is the situation not only in the Balkans but around the world.

In reality, the extent of the situation exceeds what the official described above. First, Turkey economically and politically supported the international operations of other Turkish Islamic religious organisations more explicitly, particularly after 2016, in order to weaken the Gülen Movement. Although the representatives from the religious community organisations I interviewed considered this situation pleasing, local political actors questioned whether these groups' understanding of religion was consistent with that of their own countries. Second, both the Gülen-AKP struggle and the synthesised product of religion and nationalism in its perception of civilisation prompted Turkey's further instrumentalisation of religion and religious institutions in a relatively more aggressive manner, especially after 2016. Due to this newfound aggression, countries such as Austria and France considered expelling Turkey's Islamic institutions, while nations such as Cuba and Haiti remain deeply unsatisfied with being platforms for Turkey's cross-border competition of Islamic demonstration that it entered with other Muslim nations. Additionally, Balkan 
Muslims, while satisfied with the influence of Turkey's religious institutions, complain of exploitation as Turkey's means of economic assistance and sanction. The previous Head Mufti of the Muslim Community of Albania Skëndër Bruçaj best expressed this complaint:

Whether we need Turkey's economic or religious assistance is a separate issue, but its use of a club is wrong. We are an independent institution with a history spanning more than 100 years. Albanian Muslims elect us, and we are accountable to them. Turkey is certainly our friend and brother, but we want to know that we are not the same. They are building mosques, for which we are thankful, and they provide material and other multifaceted assistance. But they later rise up, acting as if they are our commander. We are not a public servant in Turkey; they need to understand that.

Turkey began to utilise religion more frequently after 2013 in foreign policy, based on swelling authoritarianism, and later based on changes in domestic politics. But this manipulation neither became multidimensional nor spawned multidimensional reactions. Policy makers and some Muslim elite were bothered by the implementation of security, stability and Islamic institutions as a means of punishment, despite being content with one aspect of these policies.

\section{Conclusions}

While debates of religion feature its internal impacts and those in countless domains after 1980, the context of religious soft power within these discussions is a prominent issue that receives minimal exploration and to which a comprehensive definition has not been applied. Religious soft power used with both positive and negative invocations in this context is generally used to define multinational institutions or, for various purposes, lawful or unlawful organisations. Nevertheless, discussions have erupted recently over whether nations could administer religious soft power as an instrument of influence in foreign policy. These debates promote discussions of states' capacities to transnationally command religious institutions, the characteristics of regimes, historical tendencies and global repetitions (Sandal 2017). But this study critiques states' use of religious soft power through the example of Turkey and claims that any institution deemed a state will, in practice, be unable to use religion only as a means of soft power. In this regard, specifically, the interviews conducted for this study indicate that such claims are increasing in the Balkans, particularly. Therefore, one Turkey's nascent Islam-based policy, it seems, cannot simply be regarded as an element of soft power or public diplomacy.

It is clear that Turkey's policies under AKP rule have, however, different effects on different actors in different regions: some groups are rather happy with Turkey's religiously fuelled approach, while some others are seriously concerned. This is why I prefer to define Turkey as an ambiguous actor that has not instrumentalised its power and impact resources in hybrid ways. Even though one might argue that Turkey's Islam-based foreign policy and new activities could be categorised within the concept of public diplomacy, this policy preference is multifaceted and has many problematic aspects, such as the exportation of domestic conflicts, which greatly exceeds the scope of public diplomacy. Furthermore, the Islam-based transformation that Turkey is experiencing appears to have effected various results in different countries and on different actors.

Funding: This research received no external funding.

Institutional Review Board Statement: This study was conducted according to the guidelines of the Declaration of Helsinki and approved by the Institutional Review Board of University of Strasbourg.

Informed Consent Statement: Informed consent was obtained from all subjects involved in this study.

Conflicts of Interest: The author declares no conflict of interest. 


\section{References}

Al-Rasheed, Madawi. 2008. Kingdom without Borders: Saudi Political, Religious and Media Expansion. London: Hurst and Co.

Aydın-Duzgit, Senem. 2018. Foreign policy and identity change: Analysing perceptions of Europe among the Turkish public. Politics 38: 19-34. [CrossRef]

Baldwin, David A. 2012. Power and International Relations. In Handbook of International Relations. Los Angeles: SAGE Publications, pp. 273-97.

Baser, Bahar, and Ahmet Erdi Ozturk. 2017. Authoritarian Politics in Turkey: Elections, Resistance and the AKP. London: Bloomsbury Publishing.

Ben-Porat, Guy. 2013. Between State and Synagogue: The Secularization of Contemporary Israel. No. 42. Cambridge: Cambridge University Press.

Bettiza, Gregorio. 2020. States, Religions and Power: Highlighting the Role of Sacred Capital in World Politics. Washington, DC: Berkley Center for Religion, Peace, and World Affairs.

Bora, Tanil. 2003. Nationalist discourses in Turkey. The South Atlantic Quarterly 102: 433-51. [CrossRef]

Bruce, Benjamin. 2018. Governing Islam Abroad: Turkish and Moroccan Muslims in Western Europe. New York: Springer.

Capan, Zeynep Gulsah, and Ayse Zarakol. 2019. Turkey's ambivalent self: Ontological insecurity in 'Kemalism'versus 'Erdoğanism'. Cambridge Review of International Affairs 32: 263-82.

Cesari, Jocelyne. 2009. Muslims in the West after 9/11: Religion, Politics and Law. Abingdon: Routledge.

Cesari, Jocelyne. 2014. The Awakening of Muslim Democracy: Religion, Modernity, and the State. Cambridge: Cambridge University Press.

Cesari, Jocelyne. 2019. Civilization as Disciplinization and the Consequences for Religion and World Politics. The Review of Faith $\mathcal{E}$ International Affairs 17: 24-33.

Citak, Zana. 2018. National conceptions, transnational solidarities: Turkey, Islam and Europe. Global Networks 18: 377-98. [CrossRef]

Davison, Andrew. 2003. Turkey, a "secular" state?: The challenge of description. The South Atlantic Quarterly 102: 333-50. [CrossRef]

Esen, Berk, and Sebnem Gumuscu. 2016. Rising competitive authoritarianism in Turkey. Third World Quarterly 37: 1581-606. [CrossRef]

Fox, Jonathan, and Shmuel Sandler, eds. 2004. Bringing Religion into International Relations. New York: Springer.

Fox, Jonathan. 2018. An Introduction to Religion and Politics: Theory and Practice. Abingdon: Routledge.

Gill, Anthony, and Arang Keshavarzian. 1999. State building and religious resources: An institutional theory of church-state relations in Iran and Mexico. Politics \& Society 27: 431-65.

Glasius, Marlies. 2018. What authoritarianism is ... and is not: A practice perspective. International Affairs 94: 515-33. [CrossRef]

Gurses, Mehmet, and Ahmet Erdi Ozturk. 2020. Religion and Armed Conflict: Evidence from the Kurdish Conflict in Turkey. Journal for the Scientific Study of Religion 59: 327-40. [CrossRef]

Haynes, Jeffrey. 2016. Religious Transnational Actors and Soft Power. Abingdon: Routledge.

Haynes, Jeffrey. 2007. Religion and Development: Conflict or Cooperation? New York: Springer.

Insel, Ahmet. 2003. The AKP and normalizing democracy in Turkey. The South Atlantic Quarterly 102: 293-308. [CrossRef]

Ipek, Pinar. 2015. Ideas and change in foreign policy instruments: Soft power and the case of the Turkish international cooperation and development agency. Foreign Policy Analysis 11: 173-93. [CrossRef]

Irak, Daghan, and Ahmet Erdi Ozturk. 2018. Redefinition of state apparatuses: AKP's Formal-Informal Networks in the online realm. Journal of Balkan and Near Eastern Studies 20: 439-58. [CrossRef]

Jacquet, Jennifer, and Dale Jamieson. 2016. Soft but significant power in the Paris Agreement. Nature Climate Change 6: 643-46. [CrossRef]

Kadıglu, Ayse. 1998. Republican epistemology and Islamic discourses in Turkey in the 1990s. Muslim World 88: 1-21.

Kaya, Ayhan. 2015. Islamisation of Turkey under the AKP rule: Empowering family, faith and charity. South European Society and Politics 20: 47-69. [CrossRef]

Keyman, Emin Fuat. 2007. Modernity, secularism and Islam: The case of Turkey. Theory, Culture E society 24: 215-34.

Kuru, Ahmet T. 2007. Changing perspectives on islamism and secularism in Turkey: The Gülen Movement and the AK Party. Paper presented at Muslim World in Transition: Contributions of the Gülen Movement, London, UK, October 25-27; pp. 140-51.

Kuru, Ahmet T. 2009. Secularism and State Policies toward Religion: The United States, France, and Turkey. Cambridge: Cambridge University Press.

Lee, Jack T. 2015. Soft power and cultural diplomacy: Emerging education hubs in Asia. Comparative Education 51: 353-74. [CrossRef]

Mahoney, James, and Dietrich Rueschemeyer. 2003. Comparative historical analysis. In Comparative Historical Analysis in the Social Sciences. Cambridge: Cambridge University Press, pp. 3-38.

Mandaville, Peter, and Shadi Hamid. 2018. Islam as statecraft: How governments use religion in foreign policy. In Brookings New Geopolitics of the Middle East Report. Washington, DC: The Brookings Institution.

Muftuler-Bac, Meltem. 1998. The never-ending story: Turkey and the European Union. Middle Eastern Studies 34: $240-58$.

Nye, Joseph S., Jr. 2004. Soft Power: The means to Success in World Politics. New York: PublicAffairs.

Oguzlu, Tarik. 2007. Soft power in Turkish foreign policy. Australian Journal of International Affairs 61: 81-97. [CrossRef]

Onis, Ziya. 2010. Crises and transformations in Turkish political economy. Turkish Policy Quarterly 9: 45-61.

Ostergaard-Nielsen, Eva. 2003. The politics of migrants' transnational political practices. International Migration Review 37: 760-86. [CrossRef] 
Ozdalga, Elizabeth. 2010. Transformation of Sufi-based communities in modern Turkey: The Nakşibendis, the Nurcus, and the Gülen community. In Turkey's Engagement with Modernity. London: Palgrave Macmillan, pp. 69-91.

Ozkan, Behlul. 2014. Turkey, Davutoglu and the idea of pan-Islamism. Survival 56: 119-40. [CrossRef]

Ozturk, Ahmet Erdi, and Istar Gozaydin. 2017. Turkey's constitutional amendments: A critical perspective. Research and Policy on Turkey 2: 210-24. [CrossRef]

Ozturk, Ahmet Erdi, and Semiha Sozeri. 2018. Diyanet as a Turkish foreign policy tool: Evidence from the Netherlands and Bulgaria. Politics and Religion 11: 624-48. [CrossRef]

Ozturk, Ahmet Erdi. 2016. Turkey's Diyanet under AKP rule: From protector to imposer of state ideology? Southeast European and Black Sea Studies 16: 619-35. [CrossRef]

Ozturk, Ahmet Erdi. 2018. Transformation of the Turkish Diyanet both at Home and Abroad: Three Stages. European Journal of Turkish Studies. Social Sciences on Contemporary Turkey 27. [CrossRef]

Ozturk, Ahmet Erdi. 2021. Religion, Identity and Power: Turkey and the Balkans in the Twenty-First Century. Edinburgh: Edinburgh University Press.

Philpott, Daniel. 2009. Has the study of global politics found religion? Annual Review of Political Science 12: 183-202. [CrossRef]

Rudolph, Susanne H. 2018. Transnational Religion and Fading States. Abingdon: Routledge.

Rumelili, Bahar, and Jennifer Todd. 2018. Paradoxes of identity change: Integrating macro, meso, and micro research on identity in conflict processes. Politics 38: 3-18. [CrossRef]

Sandal, Nukhet Ahu. 2017. Religious Leaders and Conflict Transformation: Northern Ireland and Beyond. Cambridge: Cambridge University Press.

Sarfati, Yusuf. 2017. How Turkey's slide to authoritarianism defies modernization theory. Turkish Studies 18: 395-415. [CrossRef]

Steiner, Kerstin. 2011. Religion and politics in Singapore-Matters of national identity and security? A case study of the Muslim minority in a secular state. A Case Study of the Muslim Minority in a Secular State 58: 107-34.

Thomas, Scott. 2005. The Global Resurgence of Religion and the Transformation of International Relations: The Struggle for the Soul of the Twenty-First Century. New York: Springer.

Toprak, Binnaz. 1981. Islam and Political Development in Turkey. vols. 32. Leiden: Brill.

Tugal, Cihan. 2013. "Resistance everywhere": The Gezi revolt in global perspective. New Perspectives on Turkey 49: 157-72. [CrossRef]

Turan, Omer. 2008. The Turkish Diyanet Foundation. The Muslim World 98: 370. [CrossRef]

Wastnidge, Edward. 2015. The modalities of Iranian soft power: From cultural diplomacy to soft war. Politics 35: 364-77. [CrossRef]

Watmough, Simon P., and Ahmet Erdi Ozturk. 2018. From ‘diaspora by design'to transnational political exile: The Gülen Movement in transition. Politics, Religion E Ideology 19: 33-52.

Wendt, Alexander. 1994. Collective identity formation and the international state. American Political Science Review, 384-96. [CrossRef]

Yavuz, M. Hakan, and Ahmet Erdi Ozturk. 2019. Turkish secularism and Islam under the reign of Erdoğan. Southeast European and Black Sea Studies 19: 1-9. [CrossRef]

Yavuz, M. Hakan. 2003. Islamic Political Identity in Turkey. Oxford: Oxford University Press on Demand.

Yavuz, M. Hakan. 2019. Understanding Turkish secularism in the 21th century: A contextual roadmap. Southeast European and Black Sea Studies 19: 55-78. [CrossRef] 